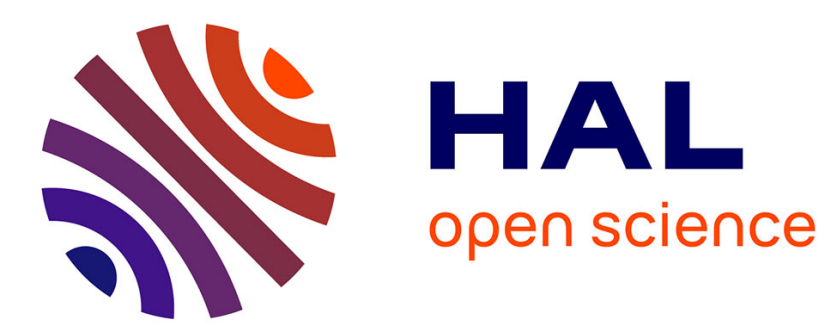

\title{
ATOM PROBE STUDY OF TITANIUM BASE ALLOYS : PRELIMINARY RESULTS
}

\author{
A. Menand, S. Chambreland, C. Martin
}

\section{To cite this version:}

A. Menand, S. Chambreland, C. Martin. ATOM PROBE STUDY OF TITANIUM BASE ALLOYS : PRELIMINARY RESULTS. Journal de Physique Colloques, 1986, 47 (C2), pp.C2-197-C2-202. 10.1051/jphyscol:1986229 . jpa-00225662

\section{HAL Id: jpa-00225662 https://hal.science/jpa-00225662}

Submitted on 1 Jan 1986

HAL is a multi-disciplinary open access archive for the deposit and dissemination of scientific research documents, whether they are published or not. The documents may come from teaching and research institutions in France or abroad, or from public or private research centers.
L'archive ouverte pluridisciplinaire HAL, est destinée au dépôt et à la diffusion de documents scientifiques de niveau recherche, publiés ou non, émanant des établissements d'enseignement et de recherche français ou étrangers, des laboratoires publics ou privés. 


\title{
ATOM PROBE STUDY OF TITANIUM BASE ALLOYS : PRELIMINARY RESULTS
}

\author{
A. MENAND, S. CHAMBRELAND and C. MARTIN \\ Laboratoire de Microscopie Ionique, UA CNRS 808, UER Sciences de \\ Rouen, BP 67, F-76130 Mont Saint Aignan. France
}

\begin{abstract}
Résumé - Deux alliages à base titane, $\mathrm{Ti}_{46} \mathrm{Al}_{54}$ et $\mathrm{Ti}_{88,8} \mathrm{Cu}_{2,3} \mathrm{~A} 1_{8,9}$, ont été étudiés à la sonde atomique. Un précipité de la phase $\mathrm{Ti}_{2} A l$ a été analysé dans 1 'alliage binaire. La microanalyse de l'alliage $\mathrm{Ti} \mathrm{Cu} A 1$ a révélé la présence de zones enrichies en Cuivre. L'étude a également mis en évidence une pénétration d'Hydrogène dans les échantillons probablement due à la technique de préparation. Les résultats obtenus démontrent la faisabilité d'études d'alliages à base titane à la sonde atomique.

Abstract - Two different titanium base alloys, $\mathrm{Ti}_{46} \mathrm{Al}_{54}$ and $\mathrm{Ti}_{88.8} \mathrm{Cu}_{2.3}$ $\mathrm{Al}_{8.9}$, have been studied by atom probe microanalysis. A precipitate of $\mathrm{Ti}_{2} \mathrm{Al}$ was analysed in the binary alloys. Micro-analys is of $\mathrm{Ti} \mathrm{Cu}$ Al alloy revealed the presence of Copper enriched zones. The study has also exhibited a penetration of Hydrogen in the samples, probably due to preparation technique. The results demonstrate the feasability of studies on titanium base alloys by mean of atom probe.
\end{abstract}

\section{I - INTRODUCTION}

Titanium base alloys are of great interest particularly in aerospace industry but, at the authors knowledge, no atom probe study has been yet reported.

We have attempted to study two types of alloys: $T_{46}{ }^{A 1_{54}}$ and $T i_{88.8} \mathrm{Cu}_{2.3}{ }^{A 1_{8.9}}$. The aim of these investigations was to determine the correct experimental conditions required to obtain reliable data on titanium base alloys.

II - EXPERIMENTAL

The alloys were supplied by 0.N. E. R. A. (Office National d'Etudes et de Recherches Aérospatiales) and were prepared by using arc melting technique.

The Field Ion Microscopy (F. I. M.) specimen were made by anodic electropolishing. $\mathrm{Ti} A 1$ samples were polished in a solution of $10 \%$ perchloric acid in 2-

Butoxyethanol. Ti Cu Al samples were prepared in an electrolyte composed of $6 \%$ perchloric acid, $34 \%$ n-butyl alcohol and $60 \%$ methanol.

The atom probe used in this study is a conventionnal one. The instrument details and performances are described elsewhere $/ 1 /$. Reliable data were obtained by using a pulse fraction of $20 \%$ of the $D C$ voltage, and a tip temperature lying between $40 \mathrm{~K}$ and $80 \mathrm{~K}$. Analyses were carried out in a vacuum of $10^{-9}$ Torr. F. I. M. observations were performed at $20 \mathrm{~K}$ and Neon gas was used for imaging.

III - RESULTS AND DISCUSSION

$\mathrm{Ti}_{46} \mathrm{A1}_{54}$

We have analysed samples prepared from alloy heat treated 10 days at $1073 \mathrm{~K}$ after 
a solution treatment of 48 hours at $1573 \mathrm{~K}$. According to A. LOISFAU et al $/ 2 /$ the Ti Al matrix has a structure $L_{1} \rho$ with $a=4 \AA$ and $c=7.6 \AA$.

As shown in figure 1 Aluminium and Titanium are detected as doubly charged ions and the five isotopes of titanium are clearly resolved.

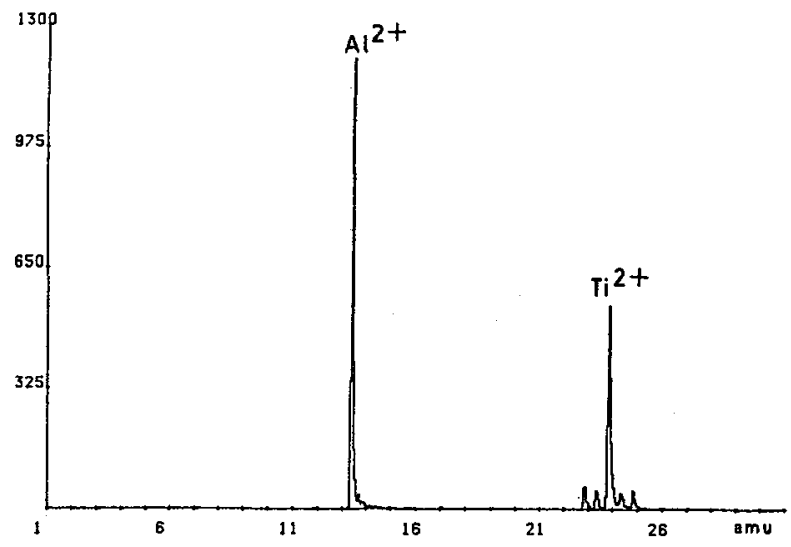

Fig. 1 - Atom probe mass spectrum of a $\mathrm{Ti}_{46} \mathrm{Al}_{54}$ sample

The composition of $\mathrm{Ti} A \mathrm{Al}$ phase is found equal to $53 \pm 3$ at $\%$ of $\mathrm{Al}$. Unfortunatiy we did not succeed to analyse reproduce iy the $T i_{2} A 1$ phase because of its very low volume fraction, and the short Tife time of tips for this very brittle alloy. Only one $\mathrm{Ti}_{2}$ Al precipitate was crossed during random area investigation of the alloy, composition profiles given in figure 2 illustrate such a situation. The composition of $\mathrm{Ti}_{2} \mathrm{Al}$ phase is founded equal to 33.7 at $\%$ of $\mathrm{Al}$.

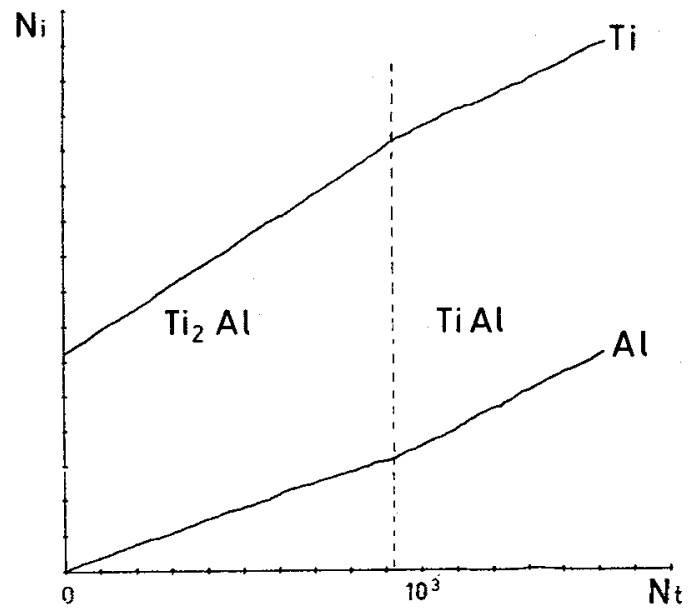

Fig. 2 - Integral composition profiles. The cumulative number of $\mathrm{Ti}$ or $\mathrm{Al}$ atoms is plotted versus the cumulative of $\mathrm{Ti}+\mathrm{Al}$ atoms. 


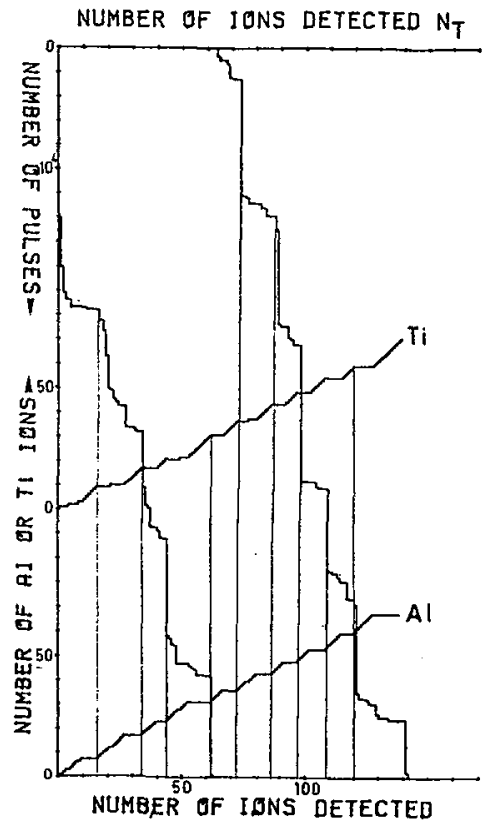

Fig. 3 - Integral composition profiles combined with the corresponding ion flux curves.

- Cumulative number of Ti or Al ions is plotted versus the cumulative number of $\mathrm{Ti}+\mathrm{AT}$ ions.

- Cumulative number of evaporation pulses is plotted versus the cumulative number of $\mathrm{T} i+\mathrm{A}$ ions.

$\mathrm{Ti}_{88} \mathrm{Cu}_{2} \mathrm{Cl}^{\mathrm{A}} 8.9$

The peculiarity of titanium-copper alloys is that age-hardening is avalaible by precipitation of copper enriched zone in the a phase. The influence of addition of a largely soluble element in the $\alpha$ phase such as aluminium contributes to a significant strengthening but reduces the kinetics of precipitation $/ 3 /$.

Analyses of alloy heat treated 28 days at $673 \mathrm{~K}$ have been performed. Titanium and aluminium are detected as doubly charged ions while copper is detected as singly and doubly charged ions. The obtained compositions over 6 samples and 25000 detected ions are given in table $\hat{i}$ and compared to the nominal values.

\begin{tabular}{|c|c|c|c|}
\hline & Ti at $\%$ & Cu at $\%$ & Al at $\%$ \\
\hline Observed composition & 89 & 1.75 & 9.25 \\
$\sigma$ & 0.2 & 0.1 & 0.2 \\
Nominal composition & 88.8 & 2.3 & 8.9 \\
\hline
\end{tabular}

Table 1

Titanium data agree well with the nominal composition whereas the copper level is a little bit too low. However, few small copper rich zones with sizes smaller than two $\mathrm{nm}$ were detected. Composition profiles shown figure 4 exhibit a well resolved $\mathrm{Cu}$ enriched region the size of which is about $1 \mathrm{~nm}$ and whose copper composition can be roughly estimated to 25 at \%.

The observed lack of copper can actually be explained in two ways. on the one hand the volume fraction of GP zones is low, atom probe data might be not representative of the overall composition. On the other hand some analyses may have been performed in copper depleted zones near a gra in boundary, where a 
solute segregation is known to occur.

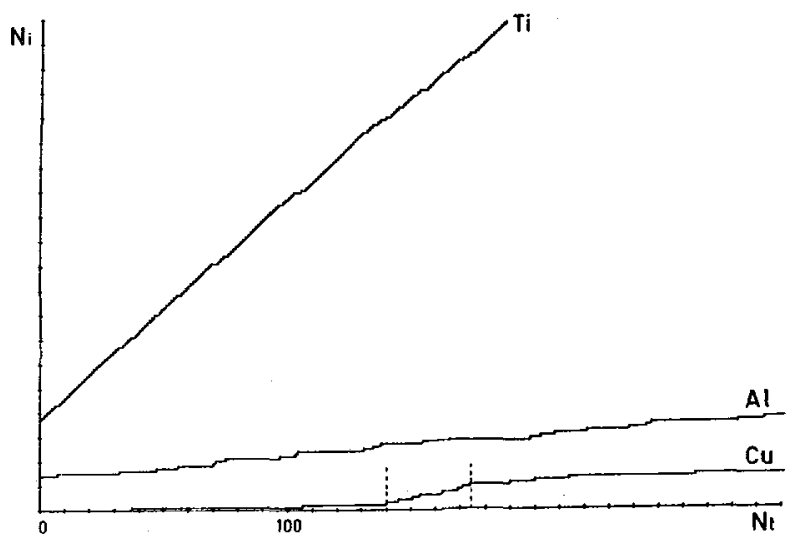

Fig. 4 - Composition profile for a Ti CU Al sample showing a copper enriched zone

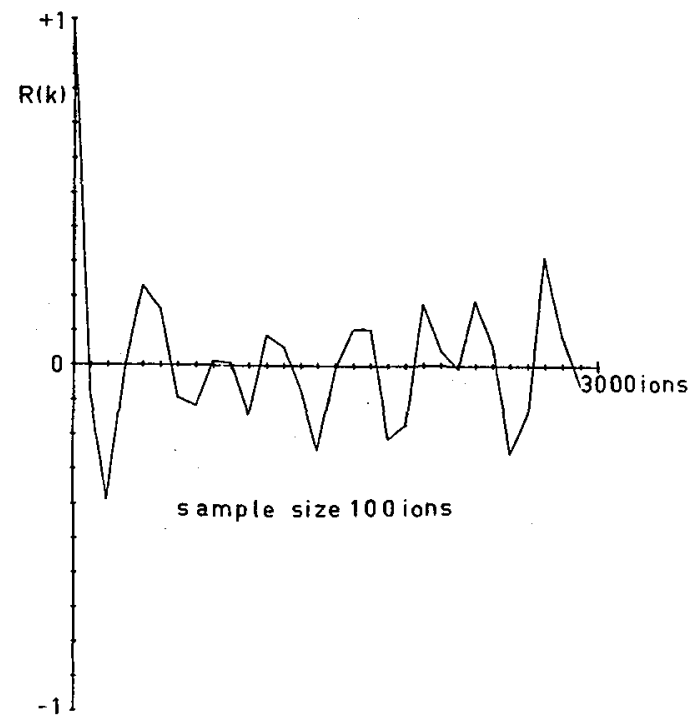

Fig. 5 - Autocorrelation function for Al in $\mathrm{Ti} \mathrm{Cu}$ Al alloy

An other interesting result concerns aluminium (figure 5) for which concentration fluctuations between 5 and 15 at $\%$ were observed with a wavelength of 400 ions (ie 5 to $6 \mathrm{~nm}$ ).

\section{Hydrogen}

A large amount of hydrogen ions was detected at the beginning of analyses of newly prepared specimens. Figure 6 illustrates this phenomenon for a $\mathrm{Ti} A 1$ sample. Although experimental conditions (pulse fraction 0.2 , repetition rate $40 \mathrm{~Hz}$, tip temperature $50 \mathrm{~K}$ ) were held constant, hydrogen was no longer received after 1000 to 3000 metal ions were detected (figure 7 ). The same result was obtained with Ti Cu Al samples (figure 8 ). 


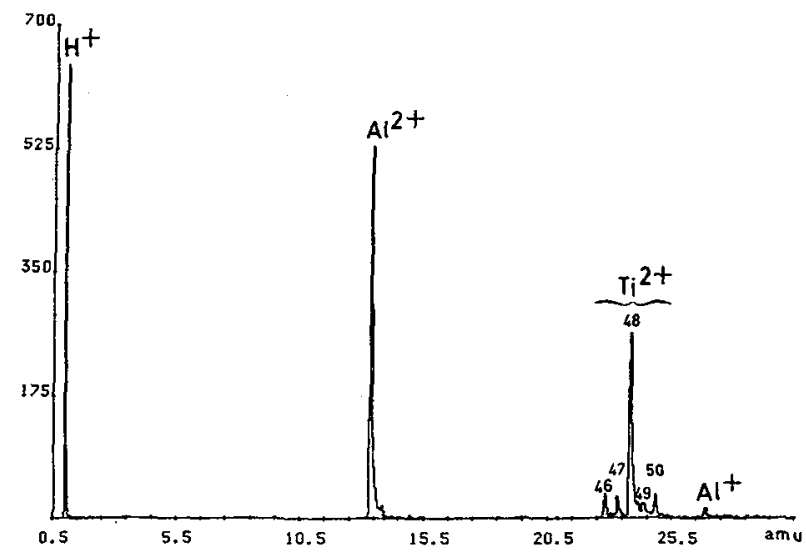

Fig. 6 - Atom probe mass spectrum of a freshly prepared Ti Al sample

Fig. 7 - Composition profiles for a freshly prepared $\mathrm{Ti} A \mathrm{~A}$ sample. The cumulative number of $H, A T$ and $T i$ ions is plotted versus the number of $\mathrm{H}+\mathrm{Al}+\mathrm{Ti}$ detected ions
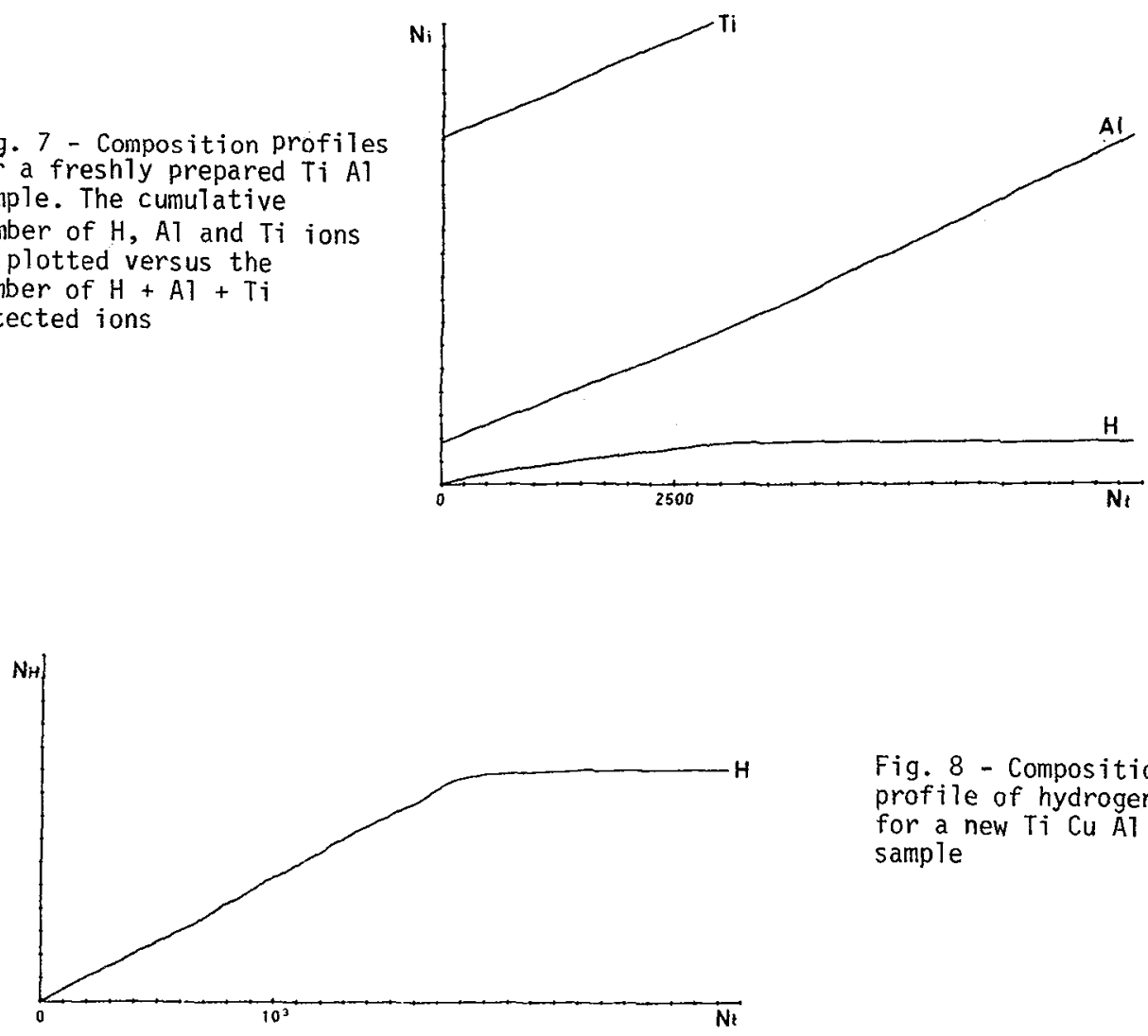

Fig. 8 - Composition profile of hydrogen for a new $\mathrm{Ti} \mathrm{CU} A \mathrm{~A}$ sample 
Our interpretation is that the major part of the observed hydrogen was introduced into the specimen during the electropolishing. The contaminated depth varies from one specimen to another but lies between a few hundred Ångströms and two thousand Angströms. The proportion of hydrogen detected ions for the contaminated zone is constant for each sample and can reach 60 at $\%$.

\section{Acknowledgments}

The study on titanium base alloys is performed in collaboration with the office National d'Etudes et de Recherches Aérospatiales (0. N. E. R. A. - Chatilion). The authors thank DrS A. LOISEAU and A. VASSEL for the fruitful and stimulating discussions.

\section{REFERENCES}

11/ Martin, C., Blavette, D., Sarrau, J. M., Rev. Phys. App1., 19 (1984) 27

12/ Loiseau, A., Lasalmonie, A., Acta Cryst., B39 (1983) 580

13/ Vasse1, A., 5th International Symposium on Titane, Münich (1983) 